\title{
GRAIN SIZE EVOLUTION AND MECHANICAL PROPERTIES OF THERMOMECHANICALLY PROCESSED PURE IRON FOR BIODEGRADABLE MEDICAL IMPLANT APPLICATION
}

\author{
C. S. Obayi \\ Dept of MetalluRgical \& MATERIALs EngR'G, University of Nigeria, NSUKKA, ENUGu STATE, NIGERIA \\ E-mail addresses: camillus.obayi@unn.edu.ng
}

\begin{abstract}
A high strength-ductility combination is a critical mechanical property requirement for biodegradable metals such as pure iron (Fe) deployed for cardiovascular implant applications. However, improving strength and ductility simultaneously is a very challenging task because strength and ductility are mutually exclusive. The main target of this work was to achieve homogeneous and fine grain structure in pure iron (Fe) that would enable adequate strengthductility combination via thermomechanical process of cold rolling and recrystallization annealing. Pure Fe samples were subjected to various degrees of cold rolling followed by recrystallization annealing at $550^{\circ} \mathrm{C}, 670^{\circ} \mathrm{C}, 800^{\circ} \mathrm{C}$ and $900^{\circ} \mathrm{C}$, microstructural examination and the mechanical property evaluation. Thermomechanical processing restored ductility, refined microstructure reducing grain size from $29.6 \mu \mathrm{m}$ to $14.6 \mu \mathrm{m}$ and $13.8 \mu \mathrm{m}$, which led to $44.7 \%$ and $48.2 \%$ increase in yield strengths for the pure Fe cold rolled to $75 \%$ and $85 \%$ reduction and annealed at $550^{\circ} \mathrm{C}$, respectively.
\end{abstract}

Keywords: grain size evolution, mechanical properties, pure iron, thermomechanical processing, biodegradable.

\section{INTRODUCTION}

Grain size is the fundamental microstructural parameter that affects all aspects of physical and mechanical behaviours of polycrystalline metals [1]. Long ago, the mechanical properties such as yield strength, ductility and hardness were found to show linear dependence with inverse square root of grain size. A high strength-ductility combination is a critical mechanical property requirement for biodegradable metals deployed for cardiovascular implant applications.

A wide variety of processing methods such casting, forging, rolling, drawing and extrusion accompanied with heat treatment has been used for ages aimed at modifying microstructure and improving the mechanical properties of metals deployed for various applications [2, 3]. An improvement in strength achieved by some of these methods comes at the expense of ductility and when accompanied by heat treatment lowers strength and improves ductility.
Thus, high strength and adequate ductility are usually mutually exclusive and improving both simultaneously is a very challenging task [1].

Pure iron ( $\geq 99.8 \%$ purity) has recently found new application as a candidate metal for biodegradable medical implant application for cardiovascular stenting [4].A cardiovascular stent is a mini or micron scale implant. Biodegradable cardiovascular stent is designed to provide a short-time mechanical opening support to severely narrowed or blocked coronary arterial wall during healing and to degrade in vivo through corrosion after implantation, without generating toxicity in the human body [5]. Other critical requirements of pure iron $(\mathrm{Fe})$ for this application include enhanced and uniform in vivo corrosion rate of about $20 \mu \mathrm{m} /$ year [6] that should match tissue healing rate, sufficient mechanical properties (yield strength $>200 \mathrm{MPa}$; tensile strength $>300 \mathrm{MPa}$ and ductility >15-18\%) [7]. Hence, the ideal Fe-based cardiovascular implant should combine

${ }^{*}$ Author, tel: +234 - $803-750-6514$ 
high strength with sufficient ductility and enhanced uniform in vivo degradation. All these properties benefit from grain size reduction [1].

In view of the difficulty of obtaining sufficient strengthductility balance during processing and the well-known dependence of mechanical properties on average grain size, this paper is targeted at refining grain structure via plastic cold rolling and recrystallization annealing with a view to achieving sufficient strengthductility combination in pure Fe. Unlike other workers, this work adopted air-cooling instead of furnacecooling during recrystallization annealing to simulate a fast cooling scenario for the pure Fe during heat treatment.

\section{MATERIALS AND METHODS}

\subsection{Materials}

The pure iron used in this work was an $\mathrm{Armco}^{\circledR}$ soft ingot iron ( $\geq 99.8 \%$ purity) in the form of $2 \mathrm{~mm}$ thick as-rolled sheets (Good fellow Limited, Cambridge, United Kingdom). Its chemical composition (wt. \%) was determined in a previous work [8] and was as follows: C: 0.006; Ni: 0.037; Cr: 0.032; Mn: 0.041; Cu: 0.017; Mo: 0.002; S: 0.014; Sn: 0.014; P: 0.019; Si: 0.008; Al: 0.010; Fe balance.

\subsection{Methods}

\subsubsection{Cold rolling and recrystallization annealing}

Specimens were cut from the $2 \mathrm{~mm}$-thick pure iron sheet and undirectionally (UD) cold rolled (CR) to $50 \%$ (UD50\%CR), 75\% (UD75\%CR) and 85\% (UD85\%CR) thickness reduction to achieve $1.0 \mathrm{~mm}, 0.5 \mathrm{~mm}$ and $0.3 \mathrm{~mm}$ thicknesses, respectively, with thickness reduction limited to $0.2 \mathrm{~mm}$ per pass at a rolling speed of $220 \mathrm{~mm} \mathrm{~s}^{-1}$ using $130 \mathrm{~mm}$ work rolls (Stanat, Rolling Mill; model TA-315).

In order to induce different grain sizes, the UD coldrolled samples were annealed in a tube furnace under a high purity argon-hydrogen atmosphere using a heating rate of $6.5^{\circ} \mathrm{C}$ per minute to $550^{\circ} \mathrm{C}, 670^{\circ} \mathrm{C}$, $800^{\circ} \mathrm{C}$ and $900^{\circ} \mathrm{C}$. The cold rolled pure iron specimens (UD50\%CR, UD75\%CR and UD85\%CR) were soaked for two hours and air cooled.

\subsubsection{Microstructure and grain size measurement}

The microstructure and grain size evolution of the asreceived, cold-rolled and annealed pure iron samples were observed on the rolling surface and determined using optical microscope (Nikon Epiphot 200, Japan) equipped with CLEMEX Vision image analyzer (Clemex, Longueuil, Canada). Prior to microstructural examination and grain size measurement, the asreceived, cold rolled and annealed samples were cut and mounted in acrylic resin and wet ground with 3201000 grit SiC papers and finally polished with $6 \mu \mathrm{m}$ and $1 \mu \mathrm{m}$ diamond suspension and $0.05 \mu \mathrm{m}$ alumina paste. They were then etched using a $2 \%$ Nital solution to expose the grains and grain boundaries.

\subsubsection{Mechanical tests}

Subsize dog-bone-shaped tensile specimens having a gauge length of $25 \mathrm{~mm}$, width of $6.38 \mathrm{~mm}$, total length of $100 \mathrm{~mm}$ and thicknesses of $2 \mathrm{~mm}$ for the asreceived $\mathrm{Fe}$ and thickness of $1.0,0.5$ and $0.3 \mathrm{~mm}$, respectively, for the rolled and annealed samples, were machined along the rolling direction following the ASTM E8 standard [9]. Tensile tests were carried out at room temperature using computer-controlled SATEC T2000 universal testing machine (SATEC T2000, USA) at a strain rate of $0.033 \mathrm{mms}^{-1}$. Three specimens were tested for each condition and the mean values and deviations from the mean were calculated.

\section{RESULTS AND DISCUSSION 3.1 Results}

\subsubsection{Microstructure and grain size of as-} received pure iron

The examined microstructure of as-received pure iron showing equiaxed ferrite grains is shown in Figure 1.

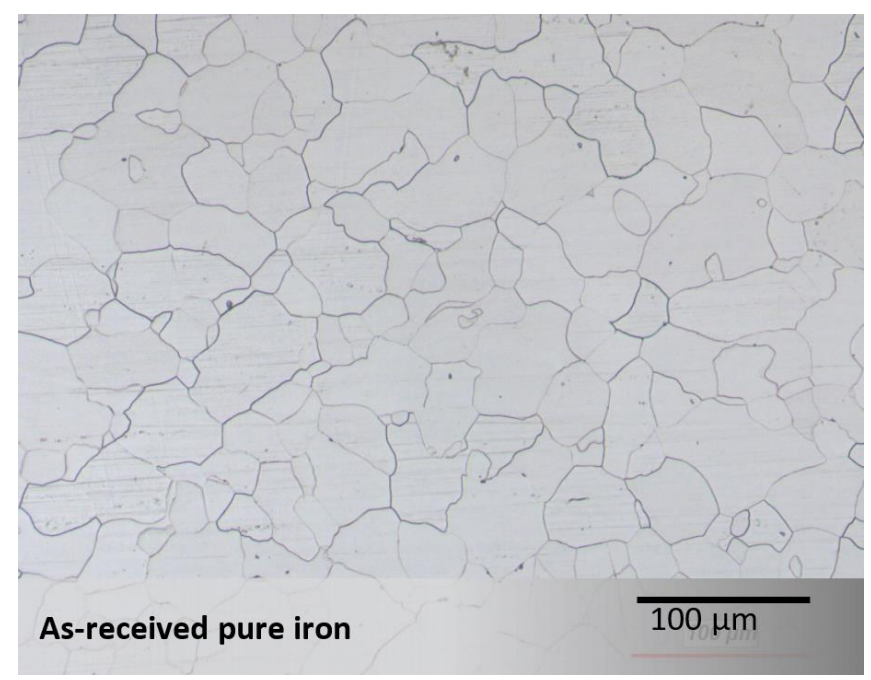

Figure 1: Micrograph of the as-received pure iron 


\subsubsection{Microstructure and average grain sizes of the processed pure iron samples}

The changes in microstructure of pure iron caused by cold rollingand determined by microscopic examination are shown in Figure 2. The micrographs of the as-rolled samples reveal that the grains are oriented in the rolling direction (Fig. $2 \mathrm{a}-2 \mathrm{c}$ ). The material processing parameters and their corresponding codes, average grain sizes for the aircooled pure iron samples are shown in Table 1. The samples were code named according to the degree of cold rolling $(\%)$, heat treatment temperature $\left({ }^{\circ} \mathrm{C}\right)$ and method of cooling $(A)$ as viz: UD50\%CR-550-A, UD50\%CR-670-A, UD50\%CR-800-A, UD50\%CR-900A, UD75\%CR-550-A, UD75\%CR-670-A, UD75\%CR800-A, UD75\%CR-900-A, UD85\%CR-550-A, UD85\%CR-670-A, UD85\%CR-800-A and UD85\%CR$900-A$, respectively. Henceforth, the samples would be referred to with the code names in the rest of this paper. Table 1 also shows grain size evolution of the cold-rolled and air-cooled pure Fe samples after heat treatment at $550^{\circ} \mathrm{C}, 670^{\circ} \mathrm{C}, 800^{\circ} \mathrm{C}$ and $900^{\circ} \mathrm{C}$ for $2 \mathrm{hrs}$, respectively. Figure 3 shows the micrographs of the pure iron samples heat-treated at $550^{\circ} \mathrm{C}$ and $900^{\circ} \mathrm{C}$, respectively, which were subjected to mechanical tests.

The as-rolled pure iron samples recrystallized with average grain sizes which decreased consistently with increase in the degree of cold work, but increased with increase in recrystallization heat treatment temperatures.

\subsubsection{Mechanical properties of the thermomechanically processed pure Fe samples}

The mechanical properties of as-received, as-rolled and heat treated pure iron samples are shown in Figure 4. The results showed that the strengths of the pure iron samples in as-rolled condition increased with the degree of cold rolling while their ductility (\% elongation) decreased with the increase in the amount of cold work.

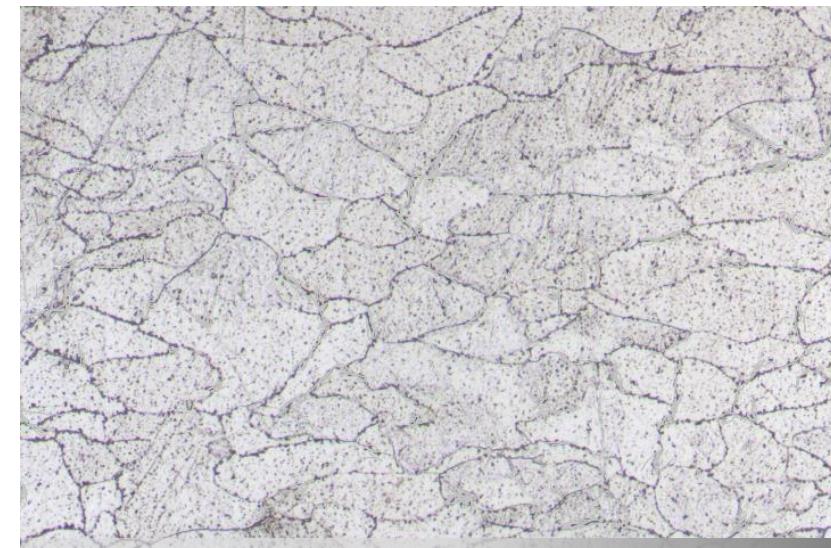

(a) UD50\%CR
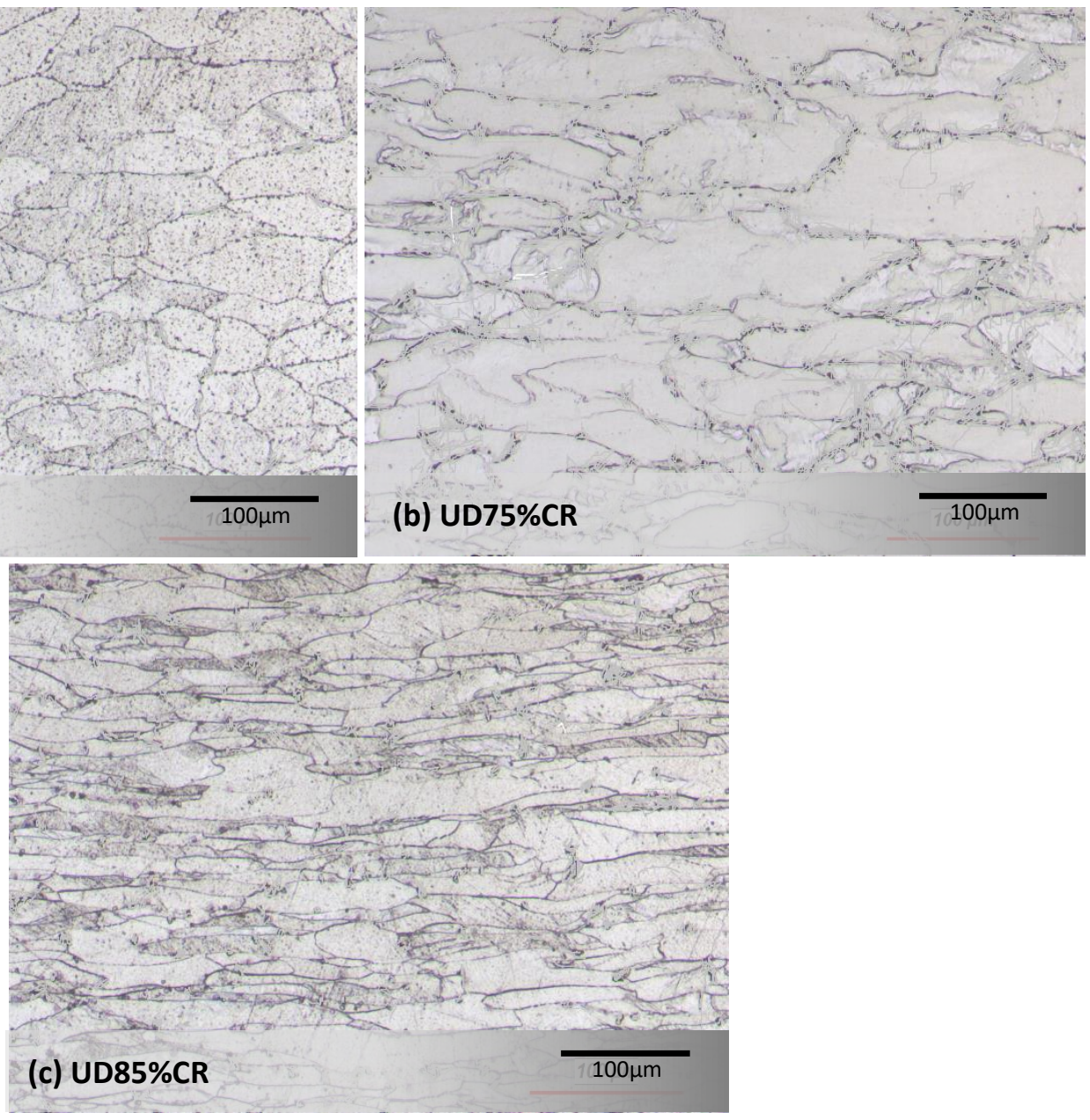

Figure 2: Changes in microstructure of pure iron caused by cold rolling, (a) UD50\%CR, (b) UD75\%CR, (c) UD85\%CR. 
Table 1: Material processing parameters and their corresponding codes and average grain sizes for the pure Fe samples

\begin{tabular}{ccccccc}
\hline S/N & Material Code & Cold-Rolling & $\begin{array}{c}\text { Cooling } \\
\text { method }\end{array}$ & $\begin{array}{c}\text { Soaking } \\
\text { Time } \\
\text { (hours })\end{array}$ & $\begin{array}{c}\text { Annealing } \\
\text { Temperature } \\
\left({ }^{\circ} \mathrm{C}\right)\end{array}$ & $\begin{array}{c}\text { Average } \\
\text { grain size } \\
(\mu \mathrm{m})\end{array}$ \\
\hline 1 & As-received & - & - & - & - & 29.6 \\
2 & UD50\%CR & Uni-directional & - & - & - & - \\
3 & UD75\%CR & Uni-directional & - & - & - & - \\
4 & UD85\%CR & Uni-directional & - & - & - & - \\
5 & UD50\%CR-550-A & Uni-directional & Air cooled & 2 & 550 & 21.4 \\
6 & UD50\%CR-670-A & Uni-directional & Air cooled & 2 & 670 & 22.1 \\
7 & UD50\%CR-800-A & Uni-directional & Air cooled & 2 & 800 & 23.7 \\
8 & UD50\%CR-900-A & Uni-directional & Air cooled & 2 & 900 & 26.5 \\
9 & UD75\%CR-550-A & Uni-directional & Air cooled & 2 & 550 & 14.6 \\
10 & UD75\%CR-670-A & Uni-directional & Air cooled & 2 & 670 & 18.0 \\
11 & UD75\%CR-800-A & Uni-directional & Air cooled & 2 & 800 & 22.4 \\
12 & UD75\%CR-900-A & Uni-directional & Air cooled & 2 & 900 & 24.0 \\
13 & UD85\%CR-550-A & Uni-directional & Air cooled & 2 & 550 & 13.8 \\
14 & UD85\%CR-670-A & Uni-directional & Air cooled & 2 & 670 & 16.9 \\
15 & UD85\%CR-800-A & Uni-directional & Air cooled & 2 & 800 & 18.6 \\
16 & UD85\%CR-900-A & Uni-directional & Air cooled & 2 & 900 & 19.5 \\
\hline
\end{tabular}

Heat treatments of the deformed pure iron samples at $550^{\circ} \mathrm{C}$ and $900^{\circ} \mathrm{C}$ led to a decrease in the strengths, but an increase in ductility. The cumulative effect of average grain size on the mechanical properties is shown in Figure 5, where strength increases and ductility decreases with reduction in grain size, respectively.

\subsection{Discussion}

\subsubsection{Average grain sizes}

The average recrystallized grain sizes of the coldrolled and air-cooled pure Fe samples generally varied with the degree of cold work and heat treatment temperatures. As shown in Table 1, the higher the degrees of cold work, the smaller the recrystallized grain size at each heat treatment temperature. The recrystallization behaviour of the cold-rolled samples might be attributed to the following reasons: An average grain size obtained by static recrystallization is a function of prior strain [10]. The amount of strain determines the rates of nucleation and subsequent grain growth of the recrystallized grains in a deformed state [2]. Cold rolling hastens grain subdivision due to the relatively higher dislocation density and substantial microstructural inhomogeneities introduced during deformation [11]. The higher the degree of cold work, the higher the nucleation rate and the smaller the final recrystallized grain size $[2,12]$.

Furthermore, a higher thickness reduction during cold rolling generally leads to an increase in stored energy of deformation and number of nucleation sites $[2,13]$. The classical theory of homogeneous nucleation [14] predicts that the number of recrystallization nuclei per unit volume, $\mathrm{N}$, is given by:

$$
N=\operatorname{Dexp}\left(-\frac{A}{K T}\right)
$$

where

$$
A=\frac{16 \pi \gamma^{3}}{3(\Delta F)^{2}}
$$

and $\gamma$ is the boundary energy between the nucleus and the matrix, $\Delta F$ is the free energy gained per unit volume by replacing the cold worked structure with strain free one and $D$ is coefficient of selfdiffusion. It is clear from Equation (1) that nucleation rate increases as either temperature or the total stored energy of deformation increases. 

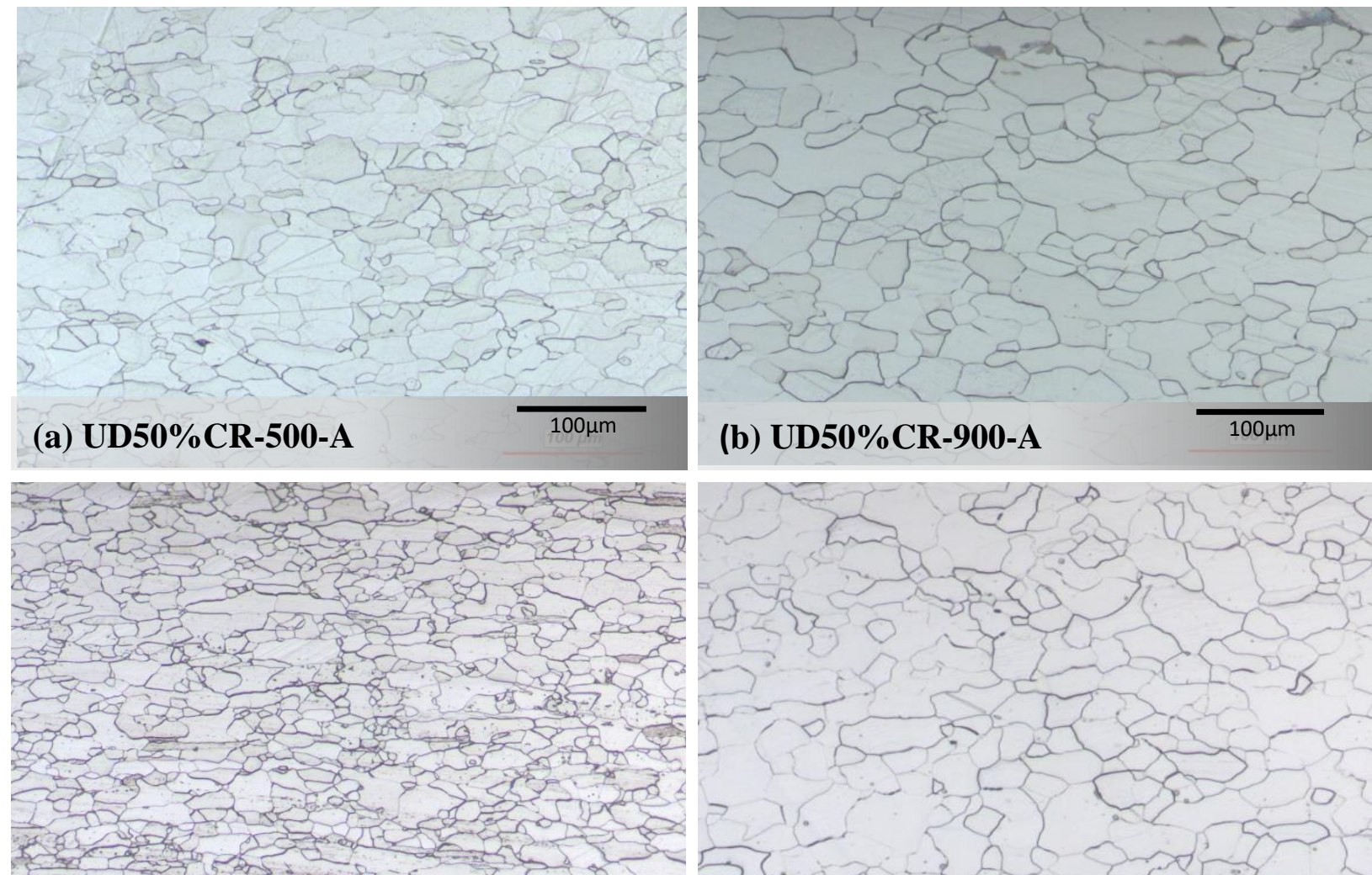

\section{(c) UD75\% CR-550-A}
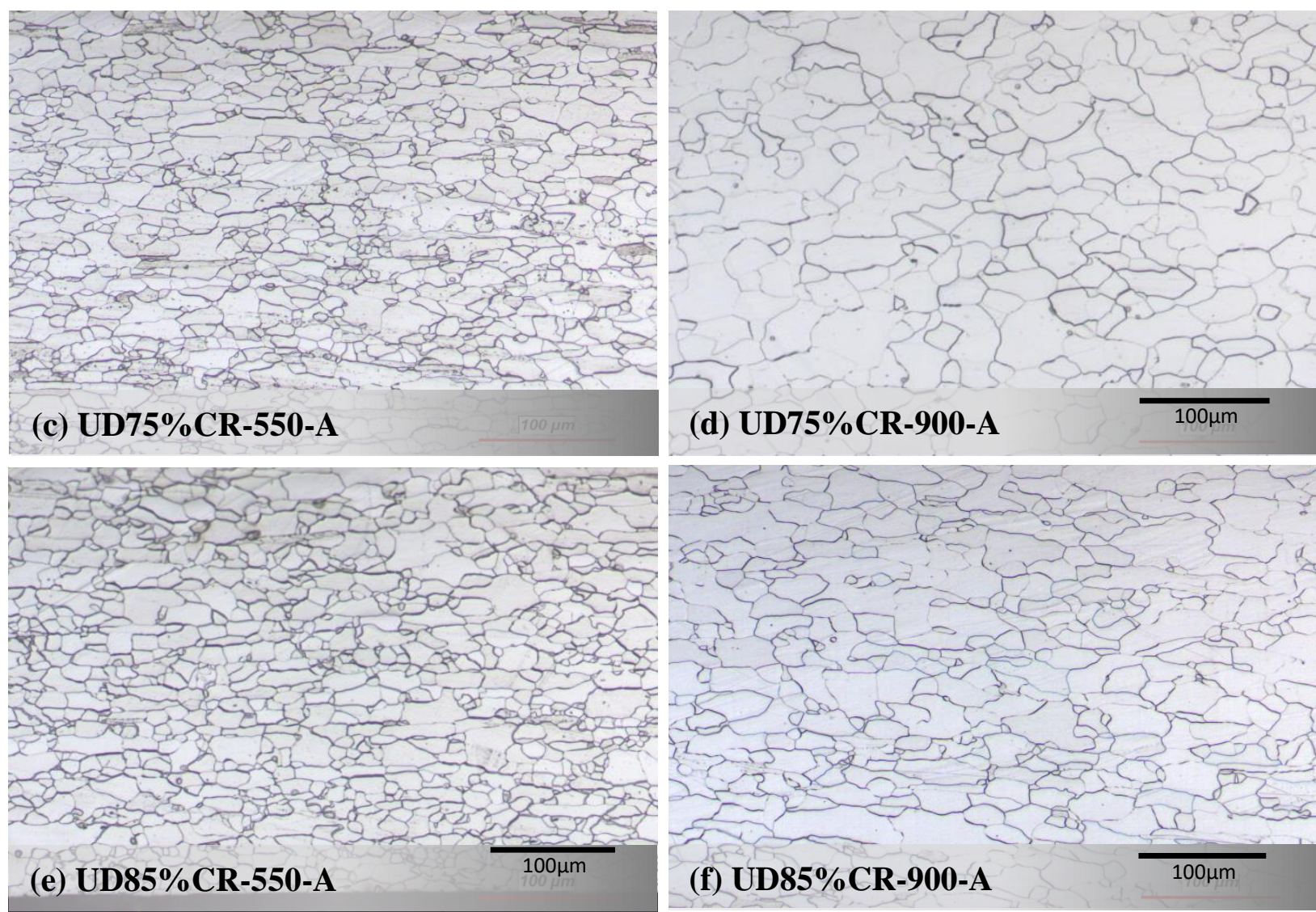

Figure 3: Micrographs of the pure iron samples heat-treated at $550^{\circ} \mathrm{C}$ and $900^{\circ} \mathrm{C}$, which were subiected to mechanical tests.

The increased stored energy of deformation and more nuclei per unit volume drives recrystallization and increases recrystallization rate respectively, resulting to smaller final grain size. The specimens cold-rolled to $85 \%$ reduction in thickness had more stored energy and recrystallized to smaller grain sizes than those cold-rolled to $50 \%$ and $75 \%$ reduction at each heat treatment temperature.

The recrystallized grain sizes of the rolled samples were smaller than the initial grain size of the asreceived pure iron $(29.6 \pm 4.5 \mu \mathrm{m})$ at the heat treatment temperature range of $550^{\circ} \mathrm{C}-900^{\circ} \mathrm{C}$. This might be due to the effect of starting grain size. Grain size obtained by static recrystallization is a function of not only prior strain but prior grain size [10]. Initial fine grains have been found beneficial for grain subdivision during cold rolling due to high dislocation density which results in smaller grain size [15]. It can also be attributed to the small thicknesses of the rolled samples ( $1 \mathrm{~mm}, 0.5 \mathrm{~mm}$ and $0.3 \mathrm{~mm}$ ), which could restrain grain growth due to sheet-thickness effect [16]. 


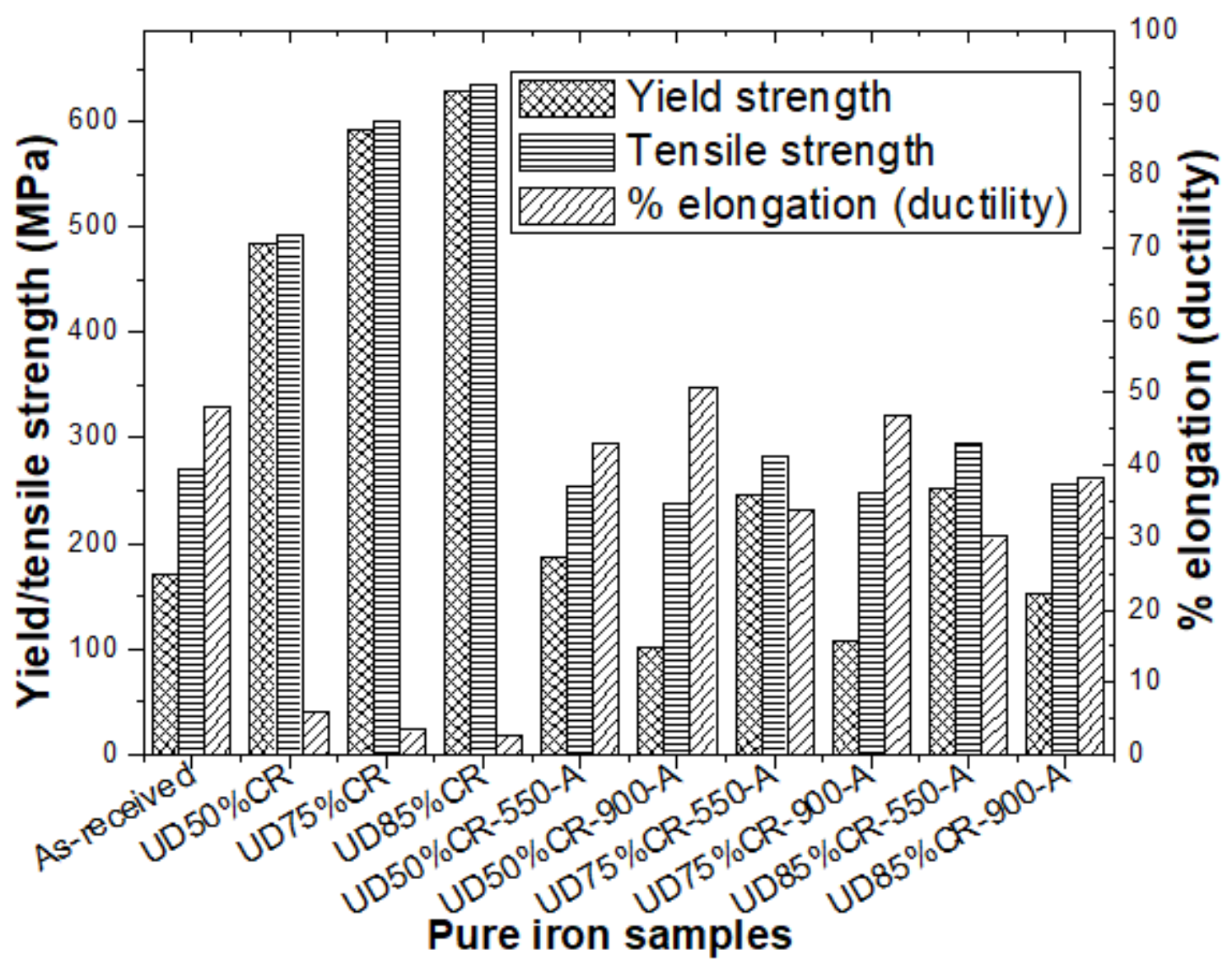

Figure 4: Mechanical properties of as-received, as-rolled and annealed pure iron samples.

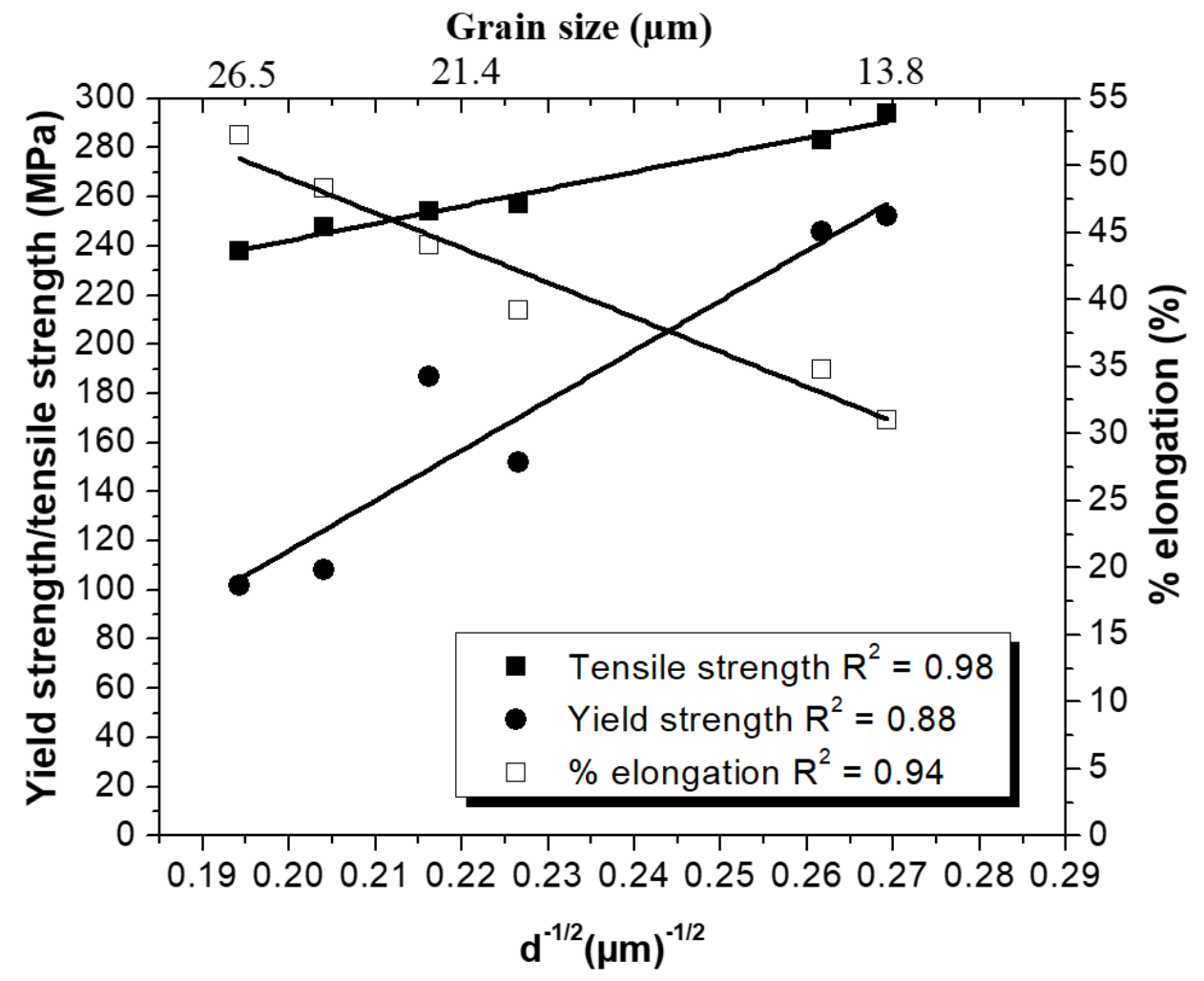

Figure 5: Effect of average grain size on the mechanical properties of air-cooled pure iron Samples 
In addition, since air-cooling is faster than furnacecooling, the recrystallized grains had no sufficient time to be merged to form larger grains at relatively higher temperature of $800^{\circ} \mathrm{C}-900^{\circ} \mathrm{C}$. Strain and cooling rates are the key parameters that govern the final grain size [11]. The faster the cooling rate the smaller the ferrite grain size of pure iron [17]. It could also be due to substitutional impurities. The asreceived pure Fe sample contained substitutional impurities ( $\mathrm{Cu}, \mathrm{Cr}, \mathrm{Mn}, \mathrm{Ni}, \mathrm{Mo}, \mathrm{S}, \mathrm{Sn}, \mathrm{P}, \mathrm{Si}, \mathrm{Al})$. Substitutional impurities especially $\mathrm{Cu}$ and $\mathrm{Cr}$ retard recrystallization and restrain grain size increase during primary recrystallization $[18,19]$.

The average recrystallized grain sizes of the rolled pure $\mathrm{Fe}$ samplesdecreased consistently with increase in the degree of cold work, but increased with increase in heat treatment temperatures in agreement with the reasons stated above $[2,10-$ 17].

Overall, the realization of smaller grain sizes for the pure Fe samples cold deformed and heat treated at $550^{\circ} \mathrm{C}$ is a plus for implant material meant for cardiovascular stent application. This is because cardiovascular stent is a miniature and micron scale implant with the average grain size of $25 \mu \mathrm{m}$ and strut thickness in the range of $70-120 \mu \mathrm{m}[20,21]$. Currently, stents are required to be made with smaller grains and to be more miniature for both mechanical and clinical reasons [21, 22]. Finegrained metals exhibit higher strengths and better host-implant interactions and excellent biocompatibilities [23].

\subsubsection{Mechanical properties of air-cooled pure Fe samples}

Cold working increases dislocation density in a polycrystalline metal which affects its mechanical properties. The strength of the as-rolled samples increased at the expense of their fracture elongation, which is a recognizable strain hardening effect of cold working. After annealing, the strength of the rolled samples decreased while their ductility increased. On the other hand, these mechanical properties were grain-size dependent. Strengths decreased with an increase in recrystallized grain size in agreement with the Hall-Petch relationship [20] while the ductility (\% elongation) increased with increase in average grain size as shown in Figure 5.The cold rolling of pure Fe to $75 \%$ and $85 \%$ reduction and annealing at $550^{\circ} \mathrm{C}$ led to a substantial increase in yield strength. The yield strengths increased from $170 \mathrm{MPa}$ to $246 \mathrm{MPa}$ (44.7\% increase) and $252 \mathrm{MPa}$ (48.2\% increase), respectively. The ductility of two pure Fe samples (UD75\%CR and UD85\%CR) annealed at $550^{\circ} \mathrm{C}$ was greater than the minimum requirement $(>15-18 \%)$ for metallic stent application. Since cardiovascular stents require sufficient strength to preserve their load-bearing function and adequate ductility for a safe deployment during implantation [8], the strength-ductility combination of the pure Fe samples cold deformed to $75 \%$ and $85 \%$ reduction and annealing at $550^{\circ} \mathrm{C}$ is adequate for the intended application.

Table 2 compared the mechanical properties of ironbased alloys for medical applications and brought to the fore the challenges in controlling strength and ductility.

Table 2: Mechanical Properties of Iron-based Alloys for Medical Implant Applications.

\begin{tabular}{llcccc}
\hline S/N & \multicolumn{1}{c}{ Metal } & $\begin{array}{c}\text { Yield } \\
\text { strength } \\
(\mathrm{MPa})\end{array}$ & $\begin{array}{c}\text { Tensile } \\
\text { strength } \\
(\mathrm{MPa})\end{array}$ & $\begin{array}{c}\text { Elongation } \\
(\%)\end{array}$ & Reference \\
\hline 1 & SS316L: annealed (ASTM F38) & 190 & 490 & 40 & {$[24]$} \\
2 & Armco Fe: annealed & 150 & 200 & 40 & {$[25]$} \\
3 & Fe-35Mn: TM treated PM alloy. & 230 & 430 & 30 & {$[26]$} \\
4 & Fe-10Mn-1Pd: heat-treated cast alloy. & $850-950$ & $1450-1550$ & $2-8$ & {$[27]$} \\
5 & Binary Fe-X (Mn, Co, Al, W, Sn, B, C, S) alloys: & $100-220$ & $190-360$ & $12-23$ & {$[28]$} \\
6 & cast. & 270 & 290 & 18 & {$[29]$} \\
7 & Electroformed Fe: annealed@550 ${ }^{\circ}$ C/1hr & 180 & 450 & 16 & {$[30]$} \\
8 & Fe-30Mn-6Si alloy: solution treated & - & $250-450$ & - & {$[31]$} \\
9 & Purecrstalline Fe: ECAP, 8 passes. & 170 & 270 & 49.3 & As-received
\end{tabular}




\begin{tabular}{llcccc}
\hline \multicolumn{1}{c}{ Metal } & \multicolumn{1}{c}{$\begin{array}{c}\text { Yield } \\
\text { strength } \\
(\mathrm{MPa})\end{array}$} & $\begin{array}{c}\text { Tensile } \\
\text { strength } \\
(\mathrm{MPa})\end{array}$ & $\begin{array}{c}\text { Elongation } \\
(\%)\end{array}$ & Reference \\
\hline 10 & $\begin{array}{l}\text { Pure Fe: CW75\%, heat-treated and air-cooled @ } \\
550^{\circ} \mathrm{C} / 2 \text { hrs. }\end{array}$ & 246 & 283 & 34.8 & This work \\
11 & $\begin{array}{l}\text { Pure Fe: } \mathrm{CW} 85 \% \text {, heat-treated and air-cooled @ } \\
550^{\circ} \mathrm{C} / 2 \text { hrs. }\end{array}$ & 252 & 294 & 31.0 & This work \\
\hline
\end{tabular}

\section{CONCLUSION}

The grain size evolution and mechanical properties of pure iron subjected to cold plastic deformation and recrystallization annealing has been investigated. The key results of this investigation are as follows:

(a) Grain size evolution was dependent on the degree of plastic deformation and recrystallization annealing temperature. The average recrystallized grain sizes of the cold rolled pure Fe samples decreased consistently with increase in the degree of cold work, but increased with increase in heat treatment temperatures.

(b) The strengths of the pure Fe samples in as-rolled condition increased at the expense of their ductility, but after annealing the strengths decreased while their ductility increased. This is because cold working increases dislocation density in polycrystalline metals and the strength and ductility of polycrystalline metals vary directly and inversely with dislocation content, respectively.

(c) The yield strengths of the pure Fe samples improved significantly with decrease in average grain size in accordance with Hall-Petch relation.

(d) Overall, recrystallization annealing refined microstructure and restored ductility and reduced strength, but both strength and ductility for pure Fe cold rolled to $75 \%$ and $85 \%$ reduction, remained at acceptable levels required for implant application after annealing at $550^{\circ} \mathrm{C}$. The cold rolling to $75 \%$ and $85 \%$ reduction and annealing at $550^{\circ} \mathrm{C}$ led to increased yield strengths from $170 \mathrm{MPa}$ to $246 \mathrm{MPa}(44.7 \%$ increase) and $252 \mathrm{MPa}$ (48.2\% increase), respectively.

\section{ACKNOWLEDGEMENT}

This work was partially supported by NSERC-Canada, CIHR-Canada, CFI-Canada, FRQ-NT-Quebec, MRI-
Quebec, Canadian Commonwealth Scholarship Program and University of Nigeria, Nsukka.

\section{REFERENCES}

[1] Estrin Y, VinogradovA. "Extreme grain refinement by severe plastic deformation: A wealth of challenging science". Acta Mater, Vol. 61, 2013; pp 782-817.

[2] F.J. Humphreys, M. Hatherly. Recrystallization and Related Annealing Phenomena ( $2^{\text {nd }}$ ed.). ELSVIER, Unite Kingdom, 2004.

[3] Tadaski Maki. @Stainless steel: Progress in thermomechanical treatment", Current Opinion in Solid State \& Materials Science, Vol. 2, 1997, pp 290-295.

[4] Peuster $M$, Wohlsein $P$, Brügmann $M$, Ehlerding $M$, Seidler K, Fink C, et al. "A novel approach to temporary stenting: degradable cardiovascular stents produced from corrodible metal-results 618 months after implantation into New Zealand white rabbits", Heart, Vol. 86, 2001, pp 563-569.

[5] Agung Purnama, Hendra Hermawan, Diego Mantovani. "Biodegradable Metal Stents: A Focused Review on Materials and Clinical Studies", Journal of Biomaterials and Tissue Engineering, Vol. 4, 2014, pp 1-6.

[6] F. Witte, N. Hort, F. Feyerabend, C. Vogt. Corrosion of Magnesium Alloys (Ed: G. Song), Woodhead, Philadelphia, PA, USA, 2011.

[7] R. J. Werkhoven, W. H. Sillekens , J. B. J. M. van Lieshout. Processing aspects of Magnesium alloy stent tube, The Minerals, Metals, and Materials Society, Warrendale, PA, USA, 2011.

[8] Obayi CS, Tolouei R, Mostavan A, Paternoster C, Turgeon S, Okorie BA, Obikwelu DO, Mantovani D. 'Effect of Grain Sizes on Mechanical Properties and Biodegradation Behavior of Pure Iron for Cardiovascular Stent Application". Biomatter, Vol. 6, Number 1, 2016.

[9] ASTM, Standard Test Methods for Tension Testing of Metallic Materials, 2013. 
[10]R. Priestner, A.K. Ibraheem. "Processing of steel for ultrafine ferrite grain structures", Mater. Sci. Technol., Vol. 16, 2000, pp 1267-1272.

[11]R. Song, D. Ponge, D. Raabe, J.G. Speer, D.K. Matlock. "Overview of processing, microstructure and mechanical properties of ultrafine grained bcc steels". Materials Science and Engineering $A$, Vol. 441, 2006, pp 1-17.

[12]C. Anthonione, F. Marino, G. Riontino, M.C. Tabasso. "Effect of Slight deformations on Grain Growth in Iron", Journal of Materials Science, Vol. 12, 1977, PP 747-750.

[13]Doherty, R.D., Hughes, D.A., Humphreys, F.J., Jonas, J.J., Juul Jensen, D., Kassner, M.E., King, W.E., McNelley, T.R., McQueen, H.J., Rollett, A.D. "Current issues in recrystallization: a review". Materials Science and Engineering A, Vol. 238, Number 2, 1997, pp 219-274.

[14]Hughes I, Page E. "The influence of manganese and carbon on plastic anisotropy, grain size, and ductility in pure iron". Metallurgical and Materials Transactions B, Vol. 2 1971, pp 2067-2075.

[15]R. Ueji, N. Tsuji, Y. Minamino, Y. Koizumi. "Ultragrain refinement of plain low carbon steel by cold-rolling and annealing of Martensite", ActaMaterialia, Vol. 50, 2002. pp 4177-4189.

[16]C. Antonione, G. Della Gatta, G. Riontino, G. venturello. "Grain Growth and Secondary Recrystallization in Iron", Journal of Materials Science, Vol. 8, 1973, pp 1-10.

[17]Toshifumi Ogawa, Nobuyuki Harima, Seiichi Takaki, Kenji Abiko. "Effect of Purity and Coolingrate on the Microstructure Hot-forged Pure Irons", Materials Transactions, Vol. 43, Number 2, 2002, pp.129-134.

[18]Antonione C, Della Gatta G, Riontino G, Venturello G. "Grain growth and secondary recrystallization in iron". Journal of Materials Science, Vol. 8, 1973, pp 1-10.

[19]C. Antonione, G. Della Gatta, A. Lucci, G. Riontino, G. Venturello. "The Role of Substitutional Elements on Recrystallization Processes in Dilute Iron Solid Solutions", Acta Metallurgica, Vol. 18, 1970, pp 1169-1180.

[20]Serruys PW, Kutryk MJB. Handbook of coronary stents. Martin Dunitz Ltd, London, 2000.

[21] Murphy BP; Cuddy H; Harewood F]; Connoley T. "The influence of grain size on the ductility of micro-scale stainless steel stent struts", Journal of Materials Science: Materials in Medicine. 2006, Vol. 17, Number 1: pp 1-6.
[22]Urgen Pache J, Kastrati A, Mehilli J, Schuhlen $H_{\text {, }}$ Dotzer F, Org Hausleiter J, Fleckenstein $M$, Neumann F-J, Sattelberger U, Schmitt C. "Intracoronary stenting and angiographic results: strut thickness effect on restenosis outcome (ISAR-STEREO-2) trial,. J Am College of Cardiol 2003; Vol. 41, pp 1283-8.

[23]Misra R, Nune C, Pesacreta T, Somani M, Karjalainen L. "Understanding the Impact of Grain Structure in Austenitic Stainless Steel from NanoGrained Regime to Coarse Grained Regime on Osteoblast Functions using a Novel Metal Deformation-Annealing Sequence", Acta Biomater 2013; 9(4):6245-58.

[24]ASTM F138-08. Standard Specification for Wrought $18 \quad$ Chromium-14 Nickel-2.5 Molybdenum Stainless Steel Bar and Wire for Surgical Implants, ASTM International: West Conshohocken, PA, USA, 2008.

[25]Hermawan, H.; Moravej, M.; Dubé, D.; Fiset, M.; Mantovani, D. "Degradation behaviour of metallic biomaterials for degradable stents", $A d v$. Mater. Res. Vol. 15-17, 2007, pp 113-118.

[26]Hermawan, H.; Alamdari, H.; D. Mantovani; Dominique Dube. "Iron-manganese: new class of metallic degradable biomaterials prepared by powder metallurgy", Powder Metallurgy, Vol. 51, Number 1, 2008, pp 38-45.

[27]Schinhammer, M.; Anja C. Hanzi; Jorg F. Loffler; Peter J. Uggowitzer. "Design strategy for biodegradable Fe-based alloys for medical applications", ActaBiomaterialia, Vol. 6, Number 5, 2010, pp 1705-1713.

[28]Liu, B.; Y.F. Zheng. "Effects of alloying elements ( Mn, Co, Al, W, Sn, B, C and S) on biodegradability and in vitro biocompatibility of pure iron". ActaBiomaterialia, Vol. 7, Number 3, 2011, pp 1407-1420.

[29]M. Moravej; A. Purnama; M. Fiset; J. Couet; D. Mantovani. "Electroformed pure iron as a new biomaterial for degradable stents: In vitro degradation and preliminary cell viability studies", Acta Biomaterialia, Vol. 6, Number 5, 2010, pp 1843-1851.

[30]Liu, B.; Y.F. Zheng; L. Ruan. "In vitro investigation of Fe30Mn6Si shape memory alloy as potential biodegradable metallic material", Materials Letters, Vol. 65, Number 3, 2010, pp 540-543.

[31]F.L. Nie; Y.F. Zheng; S.C. Wei; C. Hu; G. Yang. "In vitro Corrosion, Cytotoxicity and Hemocompatibility of Bulk Nanocrystalline Pure Iron", Biomedical Materials, Vol. 5, Number 6, .2010, pp 065015. 